\title{
PENGARUH LABA BERSIH DAN UKURAN PERUSAHAAN TERHADAP HARGA SAHAM PADA PERUSAHAAN MANUFAKTUR SEKTOR INDUSTRI BARANG KONSUMSI YANG TERDAFTAR DI BURSA EFEK INDONESIA PERIODE 2015-2019
}

\author{
Dyah Ayu Retno Inten ${ }^{1}$ \\ ${ }^{1}$ Fakultas Ekonomi Universitas Krisnadwipayana \\ Jalan Unkris Jatiwaringin Jakarta Timur \\ Handphone Penulis : 081316681735 , e-mail: dyahayuretno@yahoo.co.id \\ Dwi Rinda Permata Sari Sijabat ${ }^{2}$ \\ ${ }^{2}$ Fakultas Ekonomi Universitas Krisnadwipayana \\ Jalan Unkris Jatiwaringin Jakarta Timur \\ Handphone Penulis : 081317797553 , e-mail: dwirinda03.rpm@gmail.com
}

\begin{abstract}
Effect of Net Profit and Firm Size on Stock Prices in Manufacturing Companies in the Consumer Goods Industry Sector in 2015-2019 Indonesia Stock Exchange (IDX). This research was conducted to determine the effect of net profit and firm size on stock prices in manufacturing companies in the consumer goods industry for the period 20152019. The data used in this study are secondary data listed on the Indonesia Stock Exchange with a purposive sampling method with a research sample of 15 companies from 52 companies in the consumer goods industry sector with a period of 5 years, between year 2015 - 2019. The method of analysis used in this study is statistical test, descriptive, classical assumption test, hypothesis test. Based on this research, the results of the t test (partial) show that the net profit variable has a positive significant effect on the stock prices. Firm size has a negative significant effect on the stock prices. For the results of the F test (simultaneous) shows that the variable net profit and firm size simultaneously have a significant effect on stock price.
\end{abstract}

Keywords : Net Profit, Firm Size, Stock Price

\section{PENDAHULUAN}

Perkembangan Bursa Efek Indonesia yang terjadi pada saat ini tidak dapat dipisahkan dari peran investor yang melakukan transaksi di Bursa Efek Indonesia. Sebelum seorang investor akan memutuskan menginvestasikan dananya di pasar modal ada kegiatan yang sangat penting untuk dilakukan, yaitu penilaian yang cermat terhadap emiten (dengan membeli sekuritas yang di perdagangkan di Bursa), dan harus percaya pada informasi yang diterimanya adalah informasi yang benar. Sistem perdagangan di Bursa Efek dapat dipercaya, serta tidak ada pihak lain yang memanipulasi informasi dalam perdagangan tersebut.

Saat ini terdapat berbagai macam pilihan kegiatan bagi seseorang yang ingin melakukan investasi terhadap kekayaan yang dimilikinya. Investasi yang dapat dilakukan antara lain yaitu investasi emas, belian, tanah, dan barang berharga lainnya serta adapula investasi berupa saham. Saham adalah surat berharga yang menunjukkan bukti kepemilikan perseorangan maupun institusi maupun perusahaan. Investasi berupa saham ini dapat memberikan keuntungan kepada investor baik keuntungan ekonomis maupun non ekonomis.

Kesuksesan suatu perusahan dalam mempertahankan eksistensinya tidak luput dari peran manajer keuangan dan pengaruh keputusan keuangan yang telah dilakukan. Para manajer keuangan memiliki tugas utama yaitu merencanakan pengadaan dan penggunaan dana guna memaksimalkan nilai perusahaan.

Investor mempunyai berbagai pertimbangan untuk memutuskan sebuah 
investasi saham di pasar modal. Fluktuasi harga saham yang tidak menentu dan mengandung risiko menyebabkan ketidakpastian investor dalam menentukan keputusan investasinya. Harga saham merupakan salah satu indikator keberhasilan pengelolaan perusahaan, jika harga saham suatu perusahaan selalu mengalami kenaikan, maka investor atau calon investor menilai bahwa perusahaan berhasil dalam mengelola usahanya.

Kepercayaan investor atau calon investor sangat bermanfaat bagi emiten, karena semakin banyak orang yang percaya terhadap emiten maka keinginan untuk berinvestasi pada emiten semakin kuat. Semakin banyak permintaan terhadap saham suatu emiten maka dapat menaikkan harga saham tersebut. Jika harga saham yang tinggi dapat dipertahankan maka kepercayaan investor atau calon investor terhadap emiten juga semakin tinggi dan hal ini dapat menaikkan nilai emiten. Sebaliknya, jika harga saham mengalami penurunan terusmenerus berarti dapat menurunkan nilai emiten dimata investor atau calon investor.

Harga saham dapat menunjukkan nilai perusahaan atau emiten. Sehingga memaksimumkan nilai perusahaan dapat berarti pula memaksimumkan kekayaan pemegang saham. Harga saham mencerminkan juga nilai dari suatu perusahaan. Jika perusahaan mencapai prestasi yang baik, maka saham perusahaan tersebut akan banyak diminati oleh para investor. Tinggi rendahnya harga saham suatu perusahaan dipengaruhi oleh banyak faktor seperti: kinerja keuangan perusahaan, permintaan dan penawaran, tingkat suku bunga, tingkat resiko, laju inflasi, kebijakan pemerintah, politik dan keamanan suatu negara. Namun pada umumnya, kondisi keuangan dan kinerja keuangan perusahaan masih berpengaruh secara dominan terhadap pembentukan harga saham.
Harga saham mencerminkan nilai perusahaan. Harga pasar saham sering mengalami fluktuasi yang disebabkan oleh berbagai faktor, baik internal maupun eksternal. Adapun faktor eksternal (lingkungan makro) yang dapat mempengaruhi harga saham antara lain seperti gejolak politik dalam negeri, kondisi makro ekonomi negara yang bersangkutan, laju inflasi, perubahan suku bunga, perubahan regulasi pemerintah, dan sebagainya. Sedangkan faktor internal yang berpengaruh terhadap harga saham yaitu fundamental perusahaan, seperti kinerja keuangan dan manajemen perusahaan. Berdasarkan uraian latar belakang masalah diatas, maka penulis merumuskan masalah sebagai berikut.

1. Bagaimana pengaruh laba bersih terhadap harga saham pada perusahaan manufaktur sektor industri barang konsumsi tahun 2015-2019.

2. Bagaimana pengaruh ukuran perusahaan terhadap harga saham pada perusahaan manufaktur sektor industri barang konsumsi tahun 2015-2019.

3. Bagaimana pengaruh laba bersih dan ukuran perusahaan terhadap harga saham secara simultan pada perusahaan manufaktur sektor industri barang konsumsi tahun 2015-2019.

\section{LANDASAN TEORI}

\section{Saham}

Menurut I Ketut Tantra Riana (2015) Saham adalah surat bukti kepemilikan individu atau institusi dalam perusahaan dan merupakan tanda bukti pengambilan bagian atau peserta dalam perusahaan terbuka (PT).

Menurut Darmadji dan Fakhrudin (dalam Catarina Putri Mariska Isyani 2015) Saham dapat didefinisikan sebagai tanda penyertaan atau kepemilikan seseorang atau badan usaha dalam suatu perusahaan atau perseroan terbatas. 
Menurut Fahmi (2017) "ada beberapa pengertian saham" adalah :

1. Tanda bukti penyertaan kepemilikan modal/dana pada suatu perusahaan.

2. Kertas yang tercantum dengan jelas nilai nominal, nama perusahaan dan di ikuti dengan hak dan kewajiban yang dijelaskan kepada setiap pemegangnya.

\section{Harga Saham}

Harga saham adalah harga saham di bursa saham pada saat tertentu yang ditentukan oleh pelaku pasar dan oleh permintaan dan penawaran saham yang bersangkutan dipasar modal.

Menurut Jogiyanto (dalam Wulan Puspitasari 2016), mendefinisikan harga saham adalah harga yang terjadi dipasar bursa saat tertentu, ditentukan oleh pelaku pasar. Dan tergantung dari kekuatan permintaan dan penawaran saham yang bersangkutan di pasar modal.

Menurut Patriawan (2011), "Harga saham adalah faktor yang membuat para investor menginvestasikan dananya di pasar modal dikarenakan dapat mencerminkan tingkat pengembalian modal.

Menurut Hadi (2013), Harga Saham dapat dihitung dengan rumus sebagai berikut :

Log n (Rata-rata closing per price per quartal) (1)

Jenis-Jenis Harga Saham

Menurut Widoatmojo (2005), ada delapan jenis-jenis harga saham adalah sebagai berikut:

\section{Harga Nominal}

Harga yang tercantum dalam sertifikat saham yang ditetapkan oleh emiten untuk menilai setiap lembar saham yang dikeluarkan. Besarnya harga nominal memberikan arti penting saham karena dividen minimal biasanya ditetapkan berdasarkan nilai nominal.

\section{Harga Perdana}

Harga ini merupakan pada waktu harga saham tersebut dicatat dibursa efek. Harga saham pada pasar perdana biasanya ditetapkan oleh penjamin emisi (underwrite) dan emiten. Dengan demikian akan diketahui berapa harga saham emiten itu akan dijual kepada masyarakat biasanya untk menentukan harga perdana.

\section{Harga Pasar}

Harga pasar adalah harga jual dari investor yang satu dengan investor yang lain. Harga ini terjadi setelah saham tersebut dicatat dibursa. Transaksi di sini tidak lagi melibatkan emiten dari penjamin emisi harga ini yang disebut sebagai harga di pasar sekunder dan harga inilah yang benar-benar mewakili harga perusahaan penerbitnya, karena pada transaksi di pasar sekunder, kecil sekali terjadi negosiasi harga investor dengan perusahaan penerbit. Harga yang setiap hari diumumkan di surat kabar atau media lain adalah harga pasar.

\section{Harga pembukaan}

Harga pembukuan adalah harga yang diminta oleh penjual atau pembeli pada saat jam bursa dibuka. Bisa saja terjadi pada saat dimulainya hari nursa itu sudah terjadi transaksi atas suatu saham, dan harga sesuai dengan yang diminta oleh penjual dan pembeli. Dalam keadaan demikian, harga pembukuan bisa menjadi harga pasar, begitu juga sebaliknya harga pasar mungkin juga akan menjadi harga pembukaan. Namun tidak selalu terjadi.

\section{Harga Penutupan}

Harga penutupan adalah harga yang diminta oleh penjual atau pembeli pada saat akhir hari bursa. Pada keadaan demikian, bisa saja terjadi pada saat akhir hari bursa tiba-tiba terjadi transaksi atas suatu saham, karena ada kesepakatan antar penjual dan pembeli. Kalau ini yang terjadi maka harga penutupan itu telah menjadi harga pasar. Namun demikian, harga ini tetap menjadi harga penutupan pada hari bursa tersebut. 
6. Harga Tertinggi

Harga tertinggi suatu saham adalah harga yang paling tinggi yang terjadi pada hari bursa. Harga ini dapat terjadi transaksi atas suatu saham lebih dari satu kali tidak pada harga yang sama.

7. Harga Terendah

Harga terendah suatu saham adalah harga yang paling rendah yang terjadi pada hari bursa. Harga ini dapat terjadi apabila terjadi transaksi 12 atas suatu saham lebih dari satu kali tidak pada harga yang sama. Dengan kata lain, harga terendah merupakan lawan dari harga tertiggi.

8. Harga Rata-Rata

Harga rata-rata merupakan perataan dari harga tertinggi dan terendah.

\section{Faktor yang mempengaruhi Harga Saham}

Terdapat beberapa faktor yang dapat mempengaruhi fluktuasi harga saham di pasar modal, hal ini terjadi karena harga saham dapat mempengaruhi oleh faktor eksternal dari perusahaan maupun faktor internal perusahaan. Menurut Brigham dan Houston (2010) harga saham dipengaruhi oleh beberapa faktor utama yaitu:

1. Faktor internal

a. Pengumuman tentang pemasaran produksi penjualan seperti pengiklanan, rincian kontrak, perubahan harga, penarikan produk baru, laporan produksi, laporan keamanan, dan laporan penjualan.

b. Pengumuman pendanaan, seperti pengumuman yang berhubungan dengan ekuitas dan hutang.

c. Pengumuman badan direksi manajemen (management board of director ann nouncements) seperti perubahan dan pergantian direktur, manajemen dan struktur organisasi.

d. Pengumuman pengambilalihan diverifikasi seperti laporan merger investasi, investasi ekuitas, laporan take over oleh pengakuisisian dan diakuisisi, laporan investasi dan lainnya.

e. Pengumuman investasi seperti melakukan ekspansi pabrik pengembangan riset dan penutupan usah lainnya.

f. Pengumuman ketenagakerjaan (labour announcements), seperti negosiasi baru, kotrak baru, pemogokan dan lainnya.

g. Pengumuman laporan keuangan perusahaan, seperti peramalan laba sebelum akhir tahun fiskal dan setelah akhir tahun fiskal earning per share (EPS), dividen per shere (DPS), Price Earning Ratio, Net profit margin, return on assets (ROA) dan lain-lain.

\section{Faktor eksternal}

a. Pengumuman dari pemerintah seperti perubahan suku bunga tabungan dan deposito kurs valuta asing, inflasi, serta berbagai regulasi dan regulasi ekonomi yang dikeluarkan oleh pemerintah.

b. Penguman hukum seperti tuntutan terhadap perusahaan atau terhadap manajernya dan tuntutan perusahaan terhadap manajernya.

c. Pengumuman industri sekuritas, seperti laporan pertemuan tahunan insider trading, volume atau harga saham perdagangan pembatasan atau penundaan trading.

\section{Laba Bersih}

Menurut Soemarso (dalam Francisca Ernawari 2015) laba bersih yaitu selisih lebih semua pendapatan dan keuntungan terhadap semua biaya dan kerugian, jumlah ini merupakan kenaikan penting bagi modal.

Menurut Budi Rahardjo (2007), menyatakan bahwa Laba bersih atau laba bersih sesudah pajak penghasilan diperoleh dengan mengurangkan laba atau penghasilan sebelum 
kena pajak dengan pajak penghasilan yang harus dibayar oleh perusahaan.

Sedangkan menurut Limas Guntur Anggriono putra dan Nurul Widyawati (2014) mengatakan laba adalah kenaikan aset suatu periode akibat kegiatan produktif yang dapat dibagi atau di distribusikan kepada kreditor, pemerintah, pemegang saham (dalam bentuk bunga, pajak dan deviden) tanpa mempengaruhi keuntungan ekuitas pemegang saham semula. Laba terdiri dari hasil oprasionalnya, atau luar biasa, dan hasil-hasil non-oprasionalnya, atau keuntungan atau kerugian luar biasa, dimana jumlah keselurhannya laba bersih. Informasi mengenai sebuah laba dapat di peroleh dalam laporan keuangan yaitu, laporan laba/rugi. Informasi tersebut di gunakan oleh pihak internal atau eksternal perusahaan untuk membuat keputusan.

PSAK (2007) menyatakan bahwa laba dapat dilihat pada laporan laba bersih yang merupakan informasi tentang kinerja suatu perusahaan, dibutuhkan untuk pengambilan keputusan tentang sumber ekonomi yang akan dikelola oleh suatu perusahaan dimasa depan. Informasi tersebut juga sering kali digunakan untuk memperkirakan kemampuan suatu perusahaan untuk menghasilkan kas dan aset yang disamakan dengan kas dimasa depan. Dengan demikian laba begitu banyak memberikan informasi, tidak hanya bagi perusahaan sendiri tetapi bagi investor dan kreditor juga.

Laba bersih adalah perbedaan antar pendapatan dengan beban, jikalau pendapatan melebihi beban maka hasilnya bersih. Untuk mencari laba bersih, dapat dirumuskan sebagai berikut :

Laba Bersih $=$ Laba Sebelum Pajak - Pajak (2)

(Sumber: Henry Simamora, 2000)

Dari penjelasan diatas dapat di definisikan bahwa laba bersih adalah selisih jumlah penerimaan dengan jumlah biaya produksi. Apabila laba yang diperoleh perusahaan tinggi, maka deviden yang akan dibagikan kepada pemegang saham juga tinggi sehingga investor banyak yang tertarik untuk menanamkan investasi di perusahaan. Sebaliknya, apabila laba yang diperoleh perusahaan rendah, maka deviden yang akan dibagikan kepada pemegang sahan akan rendah sehingga akan menurunkan minat investor untuk menanamkan investasi diperusahaan

\section{Ukuran Perusahaan}

Ukuran perusahaan merupakan tolok ukur bagi suatu perusahaan untuk menentukan kapasitas perusahaan yang dimilikinya, apakah termasuk perusahaan besar atau kecil. Ukuran perusahaan dapat diukur dengan melihat keseluruhan total asset yang dimiliki perusahaan tersebut.

Dalam skala usaha terdapat berbagai ukuran perusahaan yang berbeda, dari perusahaan kecil sampai dengan perusahaan besar. Perbedaan tersebut tergantung pada investasi yang ditanamkan. Apapun ukuran perusahaannya tujuan yang ingin dicapai tetap sama yaitu suatu perusahaan didirikan adalah untuk menghasilkan laba bagi pemiliknya. Berkembangnya suatu perusahaan dari perusahaan kecil hingga menjadi besar tidak lepas dari peran manajer perusahaan dalam mengelola sumber daya pemilik perusahaan (Hariyani et al. 2011)

Ukuran perusahaan menggambarkan besar kecilnya suatu perusahaan yang dapat dinyatakan dengan total asset atau total penjualan bersih. Semakin besar total asset maupun penjualan maka semakin besar pula ukuran suatu perusahaan. Semakin besar asset maka semakin besar modal yang ditanam, sementara semakin banyak penjualan maka semakin banyak juga perputaran huang dalam perusahaan. Dengan demikian, ukuran perusahaan merupakan ukuran atau besarnya asset yang dimiliki oleh perusahaan (Mulianti, 2010). Umi Mardiyati 
(2014) menyatakan semakin besar ukuran perusahaan, asset yang didanai dengan hutang akan semakin besar pula.

Menurut Hartono (2013) Ukuran perusahaan dipakai sebagai wakil pengukur (proxy) besarnya perusahaan. Perusahaan yang besar dianggap mempunyai risiko yang lebih kecil dibandingkan dengan perusahaan yang lebih kecil. Semakin besarukuran perusahaan maka kebutuhan akan dana juga akan semakin besar yang salah satunya dapat berasal dari pendanaan eksternal yaitu hutang.

Menurut Riyanto (2013), ukuran perusahaan adalah besar kecilnya perusahaan dilihat dari besarnya nilai ekuitas, nilai penjualan atau nilai asset. Menurut Torang (2012), ukuran perusahaan adalah suatu variabel konteks yang mengukur tuntutan pelayanan atau produk organisasi.

Berdasarkan beberapa pengertian di atas maka dapat disimpulkan bahwa ukuran perusahaan merupakan nilai besar kecilnya perusahaan yang dapat ditunjukan oleh total asset, total penjualan, jumlah laba, sehingga mempengaruhi kinerja sosial perusahaan dan menyebabkan tercapainya tujuan perusahaan.

\section{Pengukuran Ukuran Perusahaan}

Ukuran perusahaan sering digunakan untuk menentukan tingkat suatu perusahaan. Perusahaan memiliki total asset, penjualan dan kapitalisasi pasar yang berbeda-beda. Ketiga hal tersebut seringkali digunakan untuk mengidentifikasi ukuran suatu perusahaan.

Menurut Werner R. Murhadi (2013) Firm Size diukur dengan mentransformasikan total asset yang dimiliki perusahaan ke dalam bentuk logaritma natural. Ukuran perusahaan diproksikan dengan menggunakan Log Natural Total Aset dengan tujuan agar mengurangi fluktuasi data yang berlebih. Dengan menggunakan log natural, jumlah asset dengan nilai ratusan miliar bahkan triliun akan disederhanakan, tanpa mengubah proporsi dari jumlah asset yang sesungguhnya.

Harahap (2013), menyatakan ukuran perusahaan diukur dengan logaritma natural (Ln) dari rata-rata total asset perusahaan. Penggunaan total asset berdasarkan pertimbangan bahwa total asset mencerminkan ukuran perusahaan dan diduga mempengaruhi ketepatan waktu.

Jogiyanto Hartono (2015), pengukuran perusahaan adalah ukuran aktiva digunakan untuk mengukur besarnya perusahaan, ukuran aktiva tersebut diukur sebagai logaritma dari total asset.

Size $=\log$ Total Asset

Menurut I Gusti Ngurah Gede Rudangga dan Gede Merta Sudiarta (2016) Ukuran perusahaan dapat dinyatakan dengan total asset yang dimiliki oleh perusahaan. Dalam ukuran perusahaan terdapat tiga variabel yang dapat menentukan ukuran perusahaan yaitu total asset, penjualan, dan kapitalisasi pasar.

\section{Kerangka Konseptual}

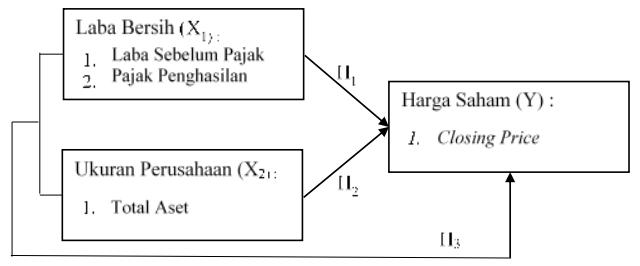

\section{Hipotesis}

$\mathrm{H1}=$ Laba bersih berpengaruh positif dan signifikan terhadap harga saham

$\mathrm{H} 2$ = Ukuran Perusahaan berpengaruh positif dan signifikan terhadap harga saham

H3 = Laba bersih dan Ukuran Perusahaan berpengaruh positif dan signifikan terhadap harga saham 


\section{METODE PENELITIAN}

Penelitian ini dilakukan di perusahaan manufaktur sektor industri barang konsumsi yang terdaftar di Bursa Efek Indonesia periode tahun 2015-2019. Instrumen penelitian ini adalah data sekunder yaitu berupa laporan keuangan dari perusahaan.

Populasi penelitian ini adalah seluruh perusahaan manufaktur sektor industri barang konsumsi yang telah go public yang terdaftar di Bursa Efek Indonesia (BEI). Terdapat 52 perusahaan manufaktur sektor industri barang konsumsi yang terdaftar di Bursa Efek Indonesia (BEI).

Tabel 1. Kriteria Sampel Perusahaan

\begin{tabular}{|c|c|c|}
\hline No & Kriteria Sampel & $\begin{array}{l}\text { Jumlah } \\
\text { Sampel }\end{array}$ \\
\hline 1. & $\begin{array}{l}\text { Perusahaan manufaktur } \\
\text { sektor industri barang } \\
\text { konsumsi yang terdaftar } \\
\text { di Bursa Efek Indonesia }\end{array}$ & 52 \\
\hline 2. & $\begin{array}{l}\text { Perusahaan manufaktur } \\
\text { sektor industri barang } \\
\text { konsumsi yang tidak } \\
\text { mempublikasikan annual } \\
\text { report secara berturut - } \\
\text { turut selama periode } \\
\text { penelitian }\end{array}$ & (21) \\
\hline 3. & $\begin{array}{l}\text { Perusahaan manufaktur } \\
\text { sektor industri barang } \\
\text { konsumsi yang tidak } \\
\text { melaporkan laporan } \\
\text { keuangannya dalam } \\
\text { satuan rupiah selama } \\
\text { periode } 2015-2019\end{array}$ & (0) \\
\hline 4. & $\begin{array}{l}\text { Perusahaan yang tidak } \\
\text { menerbitkan laporan } \\
\text { keuangan yang telah di } \\
\text { audit selama periode } \\
2015-2019\end{array}$ & (5) \\
\hline 5. & $\begin{array}{l}\text { Perusahaan mengalami } \\
\text { rugi dari tahun } 2015 \text { - }\end{array}$ & (11) \\
\hline
\end{tabular}

\begin{tabular}{|l|l|c|}
\hline \multicolumn{3}{|c|}{ Volume 9 Nomor 1 (Januari - April) 2022 } \\
\hline 6. & 2019 & 15 \\
\hline 7. & $\begin{array}{l}\text { Jumlah Sampel } \\
5)\end{array}$ & 75 \\
\hline
\end{tabular}

Tabel 2. Daftar Nama Perusahaan yang Memenuhi Kriteria

\begin{tabular}{|c|c|c|}
\hline No & $\begin{array}{c}\text { Kode } \\
\text { Perusahaan }\end{array}$ & $\begin{array}{l}\text { Nama } \\
\text { Perusahaan }\end{array}$ \\
\hline 1. & DLTA & PT. Delta Djakarta, Tbk \\
\hline 2. & ICBP & $\begin{array}{l}\text { PT. Indofood CBP Sukses } \\
\text { Makmur, Tbk }\end{array}$ \\
\hline 3. & INDF & $\begin{array}{l}\text { PT. Indofood Sukses } \\
\text { Makmur, Tbk }\end{array}$ \\
\hline 4. & MYOR & PT. Mayora Indah, Tbk \\
\hline 5. & SKLT & PT. Sekar Laut, Tbk \\
\hline 6. & STTP & PT. Siantar Top, Tbk \\
\hline 7. & ULTJ & $\begin{array}{l}\text { PT. Ultrajaya Milk } \\
\text { Industri, Tbk }\end{array}$ \\
\hline 8. & GGRM & PT. Gudang Garam, Tbk \\
\hline 9. & DVLA & $\begin{array}{l}\text { PT. Darya Varia } \\
\text { Laboratoria, Tbk }\end{array}$ \\
\hline 10. & KLBF & PT. Kalbe Farma, Tbk \\
\hline 11. & SKBM & PT. Sekar Bumi, Tbk \\
\hline 12. & ADES & $\begin{array}{l}\text { PT. Akasha Wira } \\
\text { Internasional, Tbk }\end{array}$ \\
\hline 13 & MERK & PT. Merck, Tbk \\
\hline 14. & TCID & $\begin{array}{l}\text { PT. Mandom Indonesia, } \\
\text { Tbk }\end{array}$ \\
\hline 15 & ROTI & $\begin{array}{l}\text { PT. Nippon Indosari } \\
\text { Corporindo }\end{array}$ \\
\hline
\end{tabular}

\section{HASIL PENELITIAN DAN PEMBAHASAN}

\section{H1 = Laba Bersih berpengaruh signifikan terhadap Harga Saham}

Berdasarkan hasil perhitungan statistik secara pasrsial dari Laba Bersih menunjukkan nilai koefisien bernilai positif sebesar 3,499 dengan nilai probabilitas (Sig.) yakni 0,001 < 0,05 hal ini berarti variabel Laba Bersih berpengaruh positif dan signifikan terhadap 
Harga Saham. Hasil penelitian menyatakan bahwa $\mathrm{H} 1$ diterima.

\section{H2 = Ukuran Perusahaan berpengaruh terhadap Harga Saham}

Hasil Perhitungan statistik secara parsial dari Ukuran Perusahaan menunjukan nilai koefesien benilai positif sebesar -2,529 dan dengan nilai probabilitas (Sig.) dari Ukuran Perusahaan yakni $0,014<0,05$ hal ini berarti variabel Ukuran Perusahaan berpengaruh positif signifikan terhadap Harga Saham. Hasil penelitian menyatakan bahwa $\mathrm{H} 2$ diterima.

\section{H3 = Laba bersih dan Ukuran Perusahaan berpengaruh positif dan signifikan terhadap harga saham}

Berdasarkan hasil analisis perhitungan statistik secara simultan menunjukan nilai $\mathrm{f}$ hitung sebesar 7,104 dan Nilai Sig. adalah 0,002b yang berarti $0,002 \mathrm{~b}<0,05$ maka disimpulkan bahwa seluruh variabel bebas, yakni laba bersih dan ukuran perusahaan secara simultan berpengaruh signifikan terhadap Harga Saham.

Nilai Adjusted R2 sebesar 0,165 atau sama dengan $16,5 \%$. Hal ini berarti bahwa variabel Laba Bersih dan Ukuran Perusahaan secara simultan berpengaruh terhadap variabel Harga Saham sebesar 16,5\% sedangkan sisanya $83,5 \%$ dipengaruhi oleh variabel lain yang tidak diteliti.

Hasil penelitian menyatakan bahwa $\mathrm{H} 3$ diterima.

\section{KESIMPULAN DAN SARAN}

\section{Kesimpulan}

Hasil penelitian ini dilakukan untuk mengetahui Pengaruh Laba Bersih dan Ukuran Perusahaan Terhadap Harga Saham Pada Perusahaan Manufaktur Sektor Industri Barang Konsumsi Yang Terdaftar Di Bursa Efek Indonesia (BEI) Periode 2015-2019. Hasil penelitian ini merupakan hasil pengelolahan data dengan menggunakan SPSS. Dari hasil pengujian statistic yang telah penulis lakukan dan dapat ditarik kesimpulan sebagai berikut :

1. Laba Bersih berpengaruh positif dan signifikan terhadap Harga Saham pada perusahaan manufaktur sektor industri barang konsumsi yang terdaftar di Bursa Efek Indonesia (BEI) periode 2015 - 2019. Hal ini disebabkan karena perusahaan yang bersangkutan memiliki pendapatan yang terus meningkat dari tahun sebelumnya. Semakin tinggi pendapatan maka semakin semakin tinggi keuntungan yang didapat oleh perusahaan. Keuntungan yang didapat akan menjadi tambahan modal bagi perusahaan dalam melakukan pengembangan perusahaan dalam penjualan, sehingga peluang untuk menarik minat para investor membeli saham pada perusahaan tersebut.

2. Ukuran Perusahaan berpengaruh negatif dan signifikan terhadap harga saham pada perusahaan manufaktur sektor produksi barang konsumsi yang terdaftar di Bursa Efek Indonesia (BEI) periode 2015 - 2019. Hal ini disebabkan karena besarnya ukuran perusahaan dianggap dapat menentukan besar kecilnya pada harga saham pada perusahaan. Maka perusahaan dengan aset tetap yang tinggi memiliki kesempatan besar dalam meningkatkan harga saham.

3. Laba Bersih dan Ukuran Perusahaan secara simultan berpengaruh signifikan terhadap Harga Saham. Dengan demikian dapat disimpulkan bahwa besar kecilnya perolehan Laba Bersih dan Ukuran Perusahaan memberikan pengaruh terhadap Harga Saham.Kesimpulan memuat simpulan hasil penelitiandan pembahasan tanpa angka.

\section{Saran}

Berdasarkan hasil analisis pembahasan serta kesimpulan pada penelitian ini, berikut adalah 
beberapa saran atau rekomendasi yang dapat diberikan melalui hasil penelitian ini agar mendapatkan hasil yang lebih baik yaitu:

1. Penelitian ini terbatas hanya pada perusahaan manufaktur sektor industri barang konsumsi yang terdaftar di bursa efek Indonesia. Bagi peneliti selanjutnya, objek penelitian ini dapat di perluas tidak hanya pada perusahan manufaktur sektor industri barang konsumsi saja. Dan sebaiknya di lakukan penelitian lebih lanjut terhadap beberapa variabel lain yang dapat mempengaruhi Harga Saham, agar dapat meningkatkan akurasi hasil penelitian menjadi lebih baik, dan mengetahui dengan jelas variabel lain yang mempengaruhi pada Harga Saham.

2. Penelitian ini memberikan bukti adanya pengaruh dari variabel Laba Bersih terhadap Harga Saham khususnya pada perusahaan manufaktur sektor industri barang konsumsi yang terdaftar di Bursa Efek Indonesia periode 2015-2019. Peneliti selanjutnya dapat melakukan pengujian kembali dengan periode waktu yang berbeda.

3. Bagi pembaca diharapkan untuk melakukan penelitian dan pengembangan lebih lanjut serta memperluas ruang lingkup penelitian, dan menambah objek dari berbagai sektor agar dapat memberikan referensi kepada investor, calon investor, dan pengguna lain untuk pengambilan keputusan investasi yang lebih baik. Saran memuat rekomendasi bagi pengembangan ilmu penelitian selanjutnya dan bagi perusahaan sebagai masukkan tanpa angka.

\section{DAFTAR PUSTAKA}

Budi Rahardjo. 2007. Keuangan dan Akuntansi untuk Manajer Non Keuangan. Edisi Pertama. Yogyakarta: Graha Ilmu.
Ernawati, F., \& Suwitho, S. (2015). Pengaruh

Biaya Operasional Terhadap Laba Bersih Dengan Perputaran Persediaan Sebagai Variabel Pemoderasi. Jurnal Ilmu dan Riset Manajemen (JIRM), 4(9).

Fahmi, L. Z., \& Kurnia, K. (2017). Pengaruh struktur aktiva, ukuran perusahaan, dan likuiditas terhadap struktur modal. Jurnal Ilmu Dan Riset Akuntansi (JIRA), 6(2).

Hadi, N 2013, Pasar modal: Acuan teoritis dan praktis investasi di instrumen keuangan pasar modal, Graha Ilmu, Yogyakarta.

Harahap, S. S. 2013. Analisis Kritis Atas Laporan Keuangan (Cetakan Kesebelas). Jakarta: Rajawali Pers

Hariyani, Iswi, R. Serfianto dan Cita Yustisia. 2011. Merger, Konsolidasi, Akuisisi, \& Pemisahan Perusahaan - Cara Cerdas Mengembangkan dan Memajukan Perusahaan. Jakarta: Visimedia.

Hartono, Jogiyanto. 2013. Teori Portofolio dan Analisis Investasi. Edisi Kelima. BPFE. Yogyakarta

Hartono, Jogiyanto. 2015. Teori Portofolio dan Analisis Investasi Edisi Kelima. Jakarta: Rajawali Pers.

Henry Simamora, 2000. Akuntansi Keuangan Menengah. Yogyakarta

Houston, B. (2010). Dasar-dasar Manajemen keuangan. Penerbit Salemba Empat, Jakarta.

Isyani, M., \& Putri, C. (2015). Pengaruh Return On Investment (ROI) dan Earning Per Share (EPS) Terhadap Harga Saham Perusahaan Dengan Memperhatikan Perceived Risk Saham Sebagai Variabel Moderasi Pada Perusahaan Manufaktur Yang Terdaftar di Bursa Efek Indonesia (BEI) 2011-2013. Universitas Negeri Yogyakarta. 
Liem, J. H., Murhadi, W. R., \& Sutejo, B. S. (2013). Faktor-faktor yang Mempengaruhi Struktur Modal pada Industri Consumer Goods yang Terdaftar di BEI periode 20072011. Calyptra, 2(1), 1-11.

Mardiyati, U., Susanti, S., \& Ahmad, G. N. (2014). Pengaruh kepemilikan institusional, ukuran perusahaan, profitabilitas dan risiko bisnis terhadap kebijakan hutang pada perusahaan manufaktur yang terdaftar di Bursa Efek Indonesia periode 20082012. JRMSI-Jurnal Riset Manajemen Sains Indonesia, 5(1), 84-99.

Mulianti, F. M. (2010). Analisis FaktorFaktor Yang Mempengaruhi Kebijakan Hutang Dan Pengaruhnya Terhadap Nilai Perusahaan (Studi Pada Perusahaan Manufaktur yang Terdaftar di Bursa Efek Indonesia (BEI) Periode Tahun 20042007) (Doctoral dissertation, UNIVERSITAS DIPONEGORO).

Patriawan, D., \& Sufian, S. (2011). Analisis pengaruh earning per share (EPS), return on equity (ROE), dan debt to equity ratio (DER) terhadap harga saham pada perusahaan wholesale and retail trade yang terdaftar di bursa efek indonesia (BEI) tahun 2006-2008 (Doctoral dissertation, Universitas Diponegoro).

Puspitasari, W. (2017). Analisis Pengaruh Return On Equity (Roe), Earning Per Share (Eps) Dan Debt To Equity Ratio (Der) Terhadap Harga Saham Pada Perusahaan Manufaktur Food and Beverage Yang Terdaftar di Bursa Efek Indonesia (BEI) Periode Tahun 2008-2014 (Doctoral dissertation, Universitas Muhammadiyah Surakarta).

Riana, I.K.T. and Dewi, S.K.S., 2015. Peran EPS Dalam Memediasi Pengaruh ROE Terhadap Harga Saham
Perusahaan Perbankan Di BEI. EJurnal Manajemen, 4(12).

Riyanto, Bambang. 2013. Dasar - dasar Pembelanjaan Perusahaan. Yogyakarta: BPFE

Rudangga, I. G. N. G., \& Sudiarta, G. M. (2016). Pengaruh ukuran perusahaan, leverage, dan profitabilitas terhadap nilai perusahaan. E-Jurnal Manajemen, 5(7). 